\title{
SANTO AGOSTINHO FRENTE AO PARADOXO DA MATÉRIA NA COSMOLOGIA/ONTOLOGIA PLOTINIANA NA SOLUÇÃO DO PROBLEMA DO MAL
}

\section{St. Augustine facing the paradox of matter in Plotinian cosmology/ontology in solving the problem of evil}

\section{Marcos Roberto Nunes Costa ${ }^{1}$}

\section{RESUMO}

Durante o período em que foi maniqueu, Agostinho compartilhou da ideia de que o mundo tem sua origem na junção de duas substâncias ontológicas, Deus e as Trevas, ambas de natureza corpórea. Ao encontrar Ambrósio, em Milão, este o fez pensar na possibilidade de se falar numa substância não corpórea, puramente espiritual, e que o mundo tem um único princípio Deus, que criou tudo ex nihilo. Entretanto, no que concerne à origem do mal, isso não resolvia o problema; pelo contrário, aumentava ainda mais, pois, se há apenas uma única origem ontológica de tudo - Deus, que criou tudo do nada, como não atribuir a Este a origem do mal? Foi só no encontro com o neoplatonismo, também em Milão, que Agostinho confirmaria, filosoficamente, a noção de "substância espiritual", que ouvira de Ambrósio, e, mais do que isto, despertaria para possibilidade de se falar ontologicamente do mal, não como ser, mas como não-ser ou nada. Entretanto, apesar de Plotino ter definido o não-ser (ou o nada) como o "ilimitado", o "informe", o "indeterminado", isso, para Agostinho, ainda não resolvia plenamente o problema do mal, por tratar-se ainda de uma explicação natural, quando o coloca na matéria. De qualquer maneira, a partir daí, começou a pensar o mal como que "um tirar fora", uma privação. Finalmente, no cristianismo, encontrou um lugar para o mal como algo totalmente imaterial, na livre vontade humana, que acontecer como ausência, defecção, do Bem - o não-ser.

Palavras-chave: Agostinho.Neoplatonismo.Matéria. Mal.

\begin{abstract}
During the period when he was a Manichean, Augustine shared the idea that the world has its origin in the combination of two ontological substances, God and Darkness, both of corporeal nature. When he met Ambrose in Milan, he made him think about the possibility of talking about a non-corporeal substance, purely spiritual, and that the world has a single principle - God, who created everything ex nihilo. However, as far as the origin of the evil is

\footnotetext{
${ }^{1}$ Professor efetivo do Departamento de Filosofia da Universidade Federal de Pernambuco (UFPE). Doutorado em Filosofia pela Pontifícia Universidade Católica do Rio Grande do Sul (PUCRS), Pós-doutorado em Filosofia pela Universidade do Porto. E-mail: marcosnunescosta@hotmail.com_. ORCID: https://orcid.org/0000-0003-4029-2549
} 
concerned, this did not solve the problem; on the contrary, it increased even more, since, if there is only one ontological origin of everything - God, who created everything out of nothing, how can we not attribute to Its the origin of evil? It was only in the encounter with Neoplatonism, also in Milan, that Augustine would confirm, philosophically, the notion of "spiritual substance", which he had heard from Ambrose, and, more than that, he would awaken to the possibility of speaking ontologically about evil, not as being, but as non-being or the nothing. However, although Plotinus defined nonbeing (or nothingness) as "unlimited", "unformed", "indeterminate", this, for Augustine, still did not fully solve the problem of evil, since it is still of a natural explanation, when it puts it in the matter. Anyway, from then on, he began to think of evil as "taking it out", a deprivation. Finally, in Christianity, it found a place for evil as something totally immaterial, in human free will, which happens as the absence, defection, of the Good - the non-being.

Keywords: Augustine. Neoplatonism. Matter. Bad.

\section{O despertar para o problema do mal}

Traçando uma trajetória da evolução do pensamento de Agostinho, do antes ao depois da conversão, vê-se que este se deparou com o problema do mal, do ponto de vista teórico, aos 19 anos de idade, por ocasião da leitura do Hortensius de Cícero, um dos textos estudados em meio aos seus "estudos superiores", em Cartago. Nesse momento, o mal aparece a ele como um paradoxo frente ao princípio eudemonístico despertado em seu coração pelo referido livro. Ou seja, como explicar a contradição existente entre o princípio axiomático ciceroniano, segundo o qual "todos os homens desejam, por natureza, a felicidade", e a realidade dos males praticados pelo homem, dentre os quais os cometidos pelo próprio Agostinho? O que o levou se perguntar: "Donde me veio, pois, eu querer o mal e não querer o bem?" (Conf. VII, 3, 5). Ou seja, qual a origem do mal? Indagações essas que o atormentaram e o levaram a percorrer vários caminhos (maniqueísmo, ceticismo, neoplatonismo) até que, finalmente, no cristianismo, acreditou ter encontrado respostas satisfatórias, conforme veremos no decorre deste artigo.

Entretanto, se o livro de Cícero teve o poder de despertar Agostinho do sono em que vivia, se foi uma espécie de revelação que o levou a defrontar-se com as verdades eternas, ou a Sabedoria, como ele mesmo diz: "Como ardia, Deus meu, como ardia em desejos de voar das coisas terrenas para Vós, sem saber como procedíeis comigo! Porque em Vós está a sabedo- 
ria" (Conf. III, 4, 8), o que levaria alguns autores a interpretarem isso como sendo sua primeira conversão, ou pelo menos a primeira etapa de sua conversão rumo ao cristianismo ${ }^{2}$. Entretanto, Cícero propõe a posse da felicidade, que identifica com a sabedoria-verdade eterna, por vias unicamente racionais, o que chocaria Agostinho, que, educado no cristianismo, notadamente por sua mãe Monica, não vê nenhuma relação de tal felicidade com a sabedoria-verdade cristã, ou não encontra uma mensagem cristã no referido livro. Isso o levaria a dizer: "Uma só coisa me magoava no meio de tão grande fervor: não encontrar aí o nome de Cristo" (Conf. III, 4, 8). Pois, continua, "tudo aquilo de que estivesse ausente este nome, ainda que fosse de uma obra literária burilada e verídica, nunca me arrebatava totalmente" (Ibid. III,4,8.). O que levou o comentador Frederico Sciacca (1955, p. 44) a dizer que "Agostinho não aderiu nunca a uma filosofia ou a uma doutrina sem Cristo, de quem, ainda criança, the havia falado Mônica, e que velava, inconscientemente, o dificílimo caminho de sua alma"3.

$\mathrm{Na}$ ânsia de achar uma resposta ao referido paradoxo, neste momento, vai buscar essa sabedoria-verdade na Bíblia. Mas a ausência de uma cientificidade nas Sagradas Escrituras, ou a falta de uma explicação racional para os grandes problemas do cosmos e da vida, especialmente para aquele do mal, deixou-o decepcionado, conforme ele mesmo diz nas Confissões: “Ao fixar a atenção naquelas Escrituras, não pensei então o que agora digo, senão simplesmente me pareceram indignas de comparar-se com a majestade dos escritos ciceronianos" (Conf. III, 5, 9) ${ }^{4}$.

\footnotetext{
${ }^{2}$ A atribuição da descoberta do Hortensius como primeira conversão é feita por um grupo de pesquisadores que levantam a hipótese de que houve várias conversões na vida de Agos tinho, sendo esta a primeira. Dentre estes temos O’MEARA,(1954, p. 73), que diz: “A história da leitura do Hortensius marca aquilo que certamente chamam de a primeira conversão de Agostinho. E é bem, com efeito, uma conversão, mas à filosofia - mesmo que mais tarde ela tenha se prolongado até ao Cristianismo. Num primeiro momento, pelo contrário, seu mais claro resultado foi de levar Agostinho a romper seus laços com o Cristianismo e a vir a ser maniqueu".

3 E aqui o autor observa que não só agora, mas também, mais tarde, após ler as obras neoplatônicas, Agostinho se volta para a Bíblia, quando descobriria os textos paulinos.

4 Aliás, no maniqueísmo, Agostinho também encontrava as mesmas acusações de não haver racionalidade nas Sagradas Escrituras, especialmente com referência a três pontos: 1 quanto às explicações criacionistas do mundo, e do homem à imagem e semelhança de Deus, as quais identificavam um antropomorfismo absurdo; 2 - quanto à conduta moral dos patriarcas e, por fim, 3 - por supor haver uma contradição entre o Velho e o Novo Testamento.
} 
Foi aí que entrou para a seita gnóstica dos maniqueus, na qual, paralelamente, ou seja, na mesma época em que leu o Hortensius e, em seguida, a Bíblia, vinha dando os primeiros passos.

\section{Uma solução cômoda para o problema do mal no maniqueísmo}

O maniqueísmo, ao contrário, reunia os dois elementos que Agostinho tanto queria naquele momento. Primeiro, o apreço à sabedoria, despertado pelo referido livro de Cícero, pois a sabedoria era vista nessa seita como uma verdade que se impõe à inteligência como uma certeza superior à fé, podendo o homem chegar a tal verdade por seus próprios esforços. Em segundo lugar, essa seita trazia, em seu bojo, o nome de Cristo, apresentando-se como uma religião cristã, ou melhor, como o verdadeiro cristianismo, ou seja, o maniqueísmo reunia os dois elementos que ele procurava encontrar em um único lugar 5 .

Para explicar a origem do universo, o maniqueísmo criou um sistema ontológico-cosmológico-materialista, alicerçado num dualismo ontológico, no qual aparecem dois princípios ontológicos originantes: a Luz - o Bem - e as Trevas ou a Matéria - o Mal -, ambos de naturezas corpóreas, incriadas ou coeternas, com iguais poderes de criação, ou melhor, de emanações. Da mistura e luta entre esses dois reinos surgiram os diversos seres no universo, sendo o segundo princípio - a matéria - a responsável pelos males no mundo. A partir desse dualismo ontológico, deduzia uma moral, na qual explicava a origem do mal no homem, por ser o homem uma mescla de corpo e alma, ou melhor, uma mistura das duas substâncias originárias, corpo matéria ou o Mal - e a alma - Luz ou o Bem. E assim como no universo a matéria é a responsável pelos males físicos, no homem, o corpo é a causa dos males, inclusive os morais. Melhor dito, os males no homem também são de natureza física, fruto da parte má de sua natureza, o que significa dizer que o mal moral propriamente dito não existe no maniqueísmo, ou que não há o princípio da culpa ou responsabilidade. Com isso, os maniqueus

\footnotetext{
5 A esse respeito diz BARDY(1940, p. 26): "O nome do abençoado que Agostinho tinha procurado em vão no Hortensius, ele encontra em cada página dos livros de Mani”. Igualmente O’MEARA (1954, p. 79) dá grande ênfase a esse ponto: “O mais importante de sublinhar aqui é que o maniqueísmo em geral pretendia completar a mensagem de Cristo e que, mesmo criticando o Cristianismo, ele o considerava uma parte da verdade".
} 
pensavam em isentar Deus de toda responsabilidade pelos males existentes no universo e o homem pelas maldades praticadas individualmente, conforme vemos num trecho significativo das Confissões:

Parecia-me melhor crer que não tivésseis criado nenhum mal - o qual aparecia à minha ignorância não só como uma substância, senão como uma substância corpórea, por não poder imaginar o espírito senão como um corpo sutil que se difunde pelo espaço - do que acreditar que proviesse de Vós a natureza do mal, tal qual eu imaginava [...]. Daqui deduzia eu a existência de uma certa substância do mal que tinha a sua massa feia e disforme - ou fosse grosseira como a que chamam terra ou tênue e sutil como o ar - a qual eu julgava ser o espírito maligno investindo a terra. E porque a minha piedade, como quer que ela fosse, me obrigava a crer que a bondade de Deus não criou nenhuma natureza má, estabelecia eu duas substâncias opostas a si mesmas, ambas infinitas: a do mal, mais diminuta, e a do bem, mais extensa. Deste princípio pestilencial provinham as restantes blasfêmias (Conf. V, 10, 20).

Esse foi o principal motivo que levou Agostinho a entrar e permanecer por cerca de nove anos, no maniqueísmo, acreditando que o mal que ele praticava não era responsabilidade sua, fruto de sua livre escolha, mas algo involuntário, visto estar deterministicamente marcado pela parte má de sua natureza, ou que o mal estava inerente à sua natureza corpórea.

Entretanto, apesar dessa solução cômoda, Agostinho nunca foi um maniqueu convicto; sempre se manteve desconfiado, e tal desconfiança aumentou, quando, finalmente, a partir da leitura das ciências gregas (artes liberais), especialmente da música, geometria e astronomia, encontrou alguns pontos de embaraço na doutrina e, ao buscar respostas satisfatórias, não as encontrou entre os maniqueus, nem mesmo junto ao famoso bispo Fausto. Isso o levou a se afastar, se não definitivamente, ao menos progressivamente, do maniqueísmo. Não encontrando um outro ponto onde se apoiar, passou por uma breve fase de ceticismo.

\section{O encontro com Ambrósio: primeiros passos rumo a superação do maniqueísmo}

Mas seria em Milão, aos 30 anos de idade, ao ser contratado como rector da cátedra oficial do Império, que Agostinho viria a superar definitivamente o maniqueísmo. Ao entrar em contato com o bispo Ambrósio e a filosofia neoplatônica, encontrou neles os instrumentos conceituais 
necessários para recuperar os princípios cristãos que mantinha latentes em seu coração. Esse encontro, que iria culminar, pouco tempo depois, com a conversão ao cristianismo, permitiria construir, mais tarde, sua própria explicação do problema do mal, a qual aparece como uma refutação contundente àquela seita e, por isso, recebeu o nome de "polêmica antimaniquéia".

Com as pregações de Ambrósio, Agostinho descobriu que o DeusUno do cristianismo, criador de todas as coisas, é de "substância espiritual", conceito este até então desconhecido para ele, conforme diz nas Confissões: "Eu que nem levemente ou por enigma suspeitava o que era substância espiritual, contudo alegrava-me e envergonhava-me de ter ladrado, durante tantos anos contra a fé católica [...]" (Conf., VI, 3, 4).

Pois, no maniqueísmo aprendera que todos os seres, inclusive de Deus e da alma, eram substâncias corpóreas:

[...] quanto a vós, ó Vida da minha vida, também Vos imaginava como um Ser imenso, penetrando por todos os lados a massa do Universo e alastrando-Vos fora dele, por toda a parte, através das imensidades sem limites, de tal modo que a terra, o céu e todas as coisas Vos continham e todas elas se acabavam em Vós, sem contudo acabardes em parte alguma. Mas assim como a massa do ar, deste ar que está por cima da terra, não se opõe a que a luz do sol penetre por ele, atravessando-o, sem o rasgar nem cortar, mas enchendo-o inteiramente, assim julgava que não só as substâncias transparentes do céu, do ar e do mar, mas também as da terra, eram, por Vós, penetradas em todas as suas partes, grandes e pequenas, para receberem a Vossa presença, governando-as interiormente com Vossa oculta inspiração e exteriormente dirigindo tudo o que criastes. Assim conjeturava eu, pois não Vos podia conceber de outra maneira (Conf., VII, 1, 1-2).

Além disso, Ambrósio, alicerçado na tradição de Orígenes, adotava o "método alegórico" como meio de banir das Sagradas Escrituras as contradições, os escândalos, os enganos, os mistérios que envolvem as histórias de fé. Assim, sem negar o sentido literal da Bíblia, afirmava que, para melhor compreendê-la, é preciso distinguir "a letra" e o "espírito". Ou seja, mostrar que por baixo das aparências materiais da letra, existem as verdadeiras intenções dos autores inspirados e que deve ser posto em evidência o espírito ou o sentido profundo dos ensinamentos.

Assim, com Ambrósio, Agostinho daria os primeiros passos no reencontro com a fé. Mas, no que concerne à origem do mal, as aquisições ad- 
vindas do bispo de Milão ainda não resolviam o problema; pelo contrário, aumentavam-no ainda mais, pois, se existe apenas uma única origem ontológica de tudo - Deus, que criou tudo do nada -, e não duas forças ontológicas originantes, como afirmavam os maniqueus, como não atribuir a Deus a origem do mal?

\section{A consolidação filosófica do novo paradigma ontológico no neoplatonismo}

Mas, em meio a tão grandes angústias, eis que nasceu uma luz, que Agostinho atribui como sendo a "mão oculta" de Deus, e que, nas Confissões, chama de "O colírio das dores - collyrio dolorum" (cf. Conf., VII, 8, 12). É que, em 386, através de Ambrósio, Agostinho seria apresentado ao Círculo dos Neoplatônicos de Milão, quando chegaram às suas mãos "alguns livros platônicos", conforme relata na referida obra: "E primeiro, querendo Vós mostrar-me primeiramente como 'resistis aos soberbos e dais graças aos humildes' [...], me deparastes, por intermédio de um certo homem, intumescido por monstruoso orgulho, alguns livros platônicos, traduzidos do grego para o latim" (Conf., VII, 9, 13).

Convém, portanto, que mostremos, em linhas gerais, os principais pontos da ontologia plotiniana, mais especificamente aquelas que influenciaram o ajudaram-no no processo de conversão ao cristianismo, e em que sentido contribuíram para solução do problema do mal, que é o nosso objeto de estudo no presente artigo.

\subsection{A cosmologia/ontologia plotiniana}

O ponto de partida da filosofia de Plotino está assentado no velho problema da filosofia grega, especialmente de Platão e Aristóteles, da relação entre mundo sensível e mundo inteligível.

Segundo Jolivet (cf. 1932, p. 86), apesar de sua aproximação com Platão, quando adota, pelo menos num primeiro momento, ou por questões metodológicas, o seu dualismo, Plotino aponta para um sistema monista, onde, tentando superar o mestre, procura mostrar que seu dualismo não é composto de dois elementos opostos e independentes ontologicamente como 
naquele, mas, pelo contrário, ambos os mundos - inteligível e sensitivo - têm o mesmo princípio e fim ontológico. Tudo deriva e volta ao Uno. Ou seja, para o supracitado autor o dualismo plotiniano é mais metodológico que ontológico.

Para tanto, Plotino apresenta uma explicação metafísica do cosmo pela teoria da emanação, onde tudo é explicado a partir de um único ponto ontológico - o Uno. Ou seja, no Princípio, o Uno é tudo o que existe (monismo) e dele procedem todas as coisas por processão (emanatismo). Por outra, Plotino procura mostrar que a passagem do Uno à multiplicidade dos seres não é direta, mas que tudo deriva do Uno por desdobramentos ou processões, que compreendem graus diversos ou intermediários hierarquicamente dispostos da perfeição.

Para tal, mantendo seu aparente dualismo, pelo menos por questões metodológicas, Plotino, seguindo o sistema platônico, divide a realidade (o Todo) em dois mundos: mundo inteligível e mundo sensível, onde, internamente, cada um deles sofrerá desdobramentos, obedecendo à disposição hierárquica da perfeição.

Começando pelo mundo inteligível e incorpóreo, que como um todo é superior à realidade sensível, Plotino apresenta a famosa tríade composta pelas três hipóstases primordiais.

No ápice de tudo está o Uno - Deus -, o Super-Bem, que é transcendente, perfeito, eterno, infinito e necessário. Deste primeiro Princípio, emana a segunda processão, a Inteligência ou Noûs, que é uma cópia do Uno; e, embora tenha sido engendrada imediatamente pelo Uno, e, portanto, é a mais perfeita de todas as processões, esta não tem a unidade perfeita. Ela marca o início da multiplicidade, pois, não obstante ser a processão mais próxima do primeiro Princípio, a Inteligência ou Nô̂s traz em si uma divisão interna; por um lado, ela contempla diretamente o Uno, do qual é parte, e, por outro lado, ela contempla a si mesma, é razão consciente de si mesma. Ou seja, ela é, ao mesmo tempo, a Inteligência que pensa, e é, por outro lado, Ser, enquanto é pensada ${ }^{6}$.

${ }^{6}$ Fazendo um contraponto entre a relação aqui estabelecida por Plotino entre o Uno e o Nous e posição de Agostinho, diz Johannes Brachtendorf: “Agostinho rejeita a hierarquização das hipóstases de Plotino e, em particular, sua tese de que o princípio mais elevado [o Uno] está além do ser e do pensamento. Em contraste com Plotino, Agostinho define Deus 
Por fim, encerrando o mundo inteligível, temos a terceira emanação, a Alma universal ou Alma do mundo (substância espiritual), princípio animador do universo, que dá vida a todos os corpos (seres), da qual falaremos com maiores detalhes mais adiante, quando de sua relação com o mundo sensível.

Com isto, a ideia ambrosiana de "substância espiritual" seria reforçada filosoficamente, ao identificá-la em Plotino com as três hipóstases inteligíveis, chegando inclusive a relacionar, pelo menos num primeiro momento, uma delas - a Inteligência ou Nous -, com o Verbo do Evangelho de São João.

Mais tarde, nas Confissões, utilizando-se do conceito neoplatônicocristão de "substância espiritual", Agostinho denunciaria os maniqueus que, segundo ele, cometeram um grave erro ao pensar toda natureza e toda substância, inclusive Deus e a alma, como se fossem coisa corpórea, conforme diz na referida obra:

Ignorava eu que Deus é espírito e não tem membros dotados de comprimento e de largura, nem é matéria porque a matéria é menor na sua parte do que no todo. Ainda que a matéria fosse infinita, seria menor em alguma das suas partes, limitada por um certo espaço, do que na sua infinitude. Nem pode estar toda inteira em qualquer parte, como o espírito, como Deus (Conf., III, 7).

Mas o maior problema na doutrina emanatista de Plotino estava na relação entre as três hipóstases primordiais inteligíveis e as substâncias corpóreas - os seres corpóreos ou materiais, ou seja, na passagem do mundo inteligível ao mundo sensível (o velho problema da filosofia grega, conforme anteriormente). Pois, como conciliar a unidade perfeita, espiritual, eterna, infinita, imutável e necessária do Uno com a natureza finita, corporal, múltipla e contingente dos seres corpóreos, sem abandonar o monismo? ${ }^{7}$.

(seguindo Êxodo 3:14: "Eu sou o que sou") como o próprio Ser, que precede todos os seres como seu terreno imutável. Plotino atribuiu ser e pensamento para a segunda hipóstase, o Nous. Para ele, o pensamento do Nous era essencialmente um pensamento autopensado. Plotino priorizou o Uno sobre o Nous, com sua estrutura particular da auto-relacionalidade, pois toda auto-relação contém, ao lado do aspecto da identidade, um aspecto de diferença e multiplicidade" (2000, p. 17).

7 A esse respeito diz TURRADO (1995, p. 754): “A questão mais difícil para o monismo plotiniano é a matéria ou Hylê, que ele introduz em sua teoria do egresso-regresso (processão-ascensão), se bem que a reduz ao nada, ao mal ou 'privação de bem' (stêresis), ao mesmo tempo que é considerada como necessária para a existência da alma". Igualmente diz Edrisi Fernandes: "No cerne da especulação plotiniana sobre o problema do mal repou- 
Para resolver tal problema, Plotino enquadra, também, a matéria e os seres corpóreos (mundo sensível) em sua teoria da "processão", onde tudo está no Uno. Ou seja, toda a multiplicidade no mundo sensível deriva, também, em última instância, do Uno por um processo sucessivo de processões que compreendem graus diversos ou intermediários da perfeição. Há, portanto, uma continuidade ou unidade (monismo) entre os dois mundos, o inteligível e sensível, e não um dualismo radical como querem alguns.

Plotino diz que isso é possível, porque a multiplicidade dos seres corpóreos, por emanação, em nada diminui a essência do Uno, pois este pode dar sem perder. O Uno continua sendo transcendência, Super-Bem. Pois, do ponto de vista da quantidade, um ser diminui cada vez que se tira qualquer uma de suas partes, mas, do ponto de vista da qualidade é muito diferente: assim como a luz se difunde por todas as partes, sem perder nada do seu ser, e o amor maternal se multiplica, sem esgotar-se nunca, o Uno pode expandir-se por todas substâncias, espirituais e materiais, sem perder nada.

A irradiação, a luminosidade do Uno, perpassa tudo, até ao grau mais ínfimo (a matéria), que é o extremo oposto ao primeiro Princípio (Uno). Assim, tanto as três hipóstases do mundo inteligível como as substâncias materiais, serão consideradas como expressões ou emanações de sua plenitude infinita, onde, de forma deterministicamente hierárquica, a Inteligência procede do Uno, como os raios emanam do sol; por sua vez, a Inteligência que é fecunda, engendra a Alma do mundo, com a qual chegamos aos limites do mundo inteligível e tocamos na origem do mundo sensível. A Alma do mundo, por sua vez, fecunda o ser ou a matéria, último grau da processão, lugar da multiplicidade e, portanto, princípio, ou melhor, possibilidade do mal.

Portanto, como se vê, à Alma universal cabe o papel de fazer a transição ou garantir a unidade entre o mundo inteligível e o mundo sensível. Ou seja, diz Plotino nas Enéadas,

sa a equiparação entre a matéria sensível e o "Mal em si" (Enéadas, I.8.3-4 e 7-9; I.8.8; I.8.13), o que parece condenar essa especulação à inconsistência lógica quando se sabe que Plotino associa o Bem ao Uno e entende que tudo o que existe no mundo é lógica e ontologicamente contingente em relação ao Uno/Bem e que, desse modo, até mesmo a matéria sensível, equivalente ao mal, seria contingente em relação ao Bem” (2013, p. 128). 
por ocupar um grau intermediário entre os seres, embora pertencendo ao convívio divino, a Alma está, não obstante, no último grau do reino do espírito e, confinando com o ser sensível, dá algo de si mesma a esse nosso mundo e, em contrapartida, recebe algo dele $(E n . \mathrm{IV}, 8,7$.$) .$

Para Plotino, isso só é possível, porque a Alma universal, analogamente ao que acontece com a segunda hipóstase (a Inteligência), traz em si uma divisão interna, ou uma dupla natureza; por um lado, ela é atividade intelectiva (Alma superior), voltada a contemplar o Uno, sua principal vocação, embora não o conheça diretamente, mas através da segunda hipóstase, ou seja, das imagens, dos conceitos ou formas existentes no mundo das ideias da Inteligência. Por outro lado, ela relaciona-se com o mundo sensitivo (Alma inferior), onde, assim como no caso do Uno, multiplicando-se, sem dividir-se ou perder sua unidade (cf. En. III, 1, 8, 1), dando forma à massa informe - à matéria, gerando os seres corpóreos.

Desse modo, paralelamente ao que acontece no mundo das hipóstases inteligíveis, há, também, no mundo sensível, um descenso de bens a partir do Uno. Ou num sentido inverso, de modo hierarquicamente ascendente, todas as coisas que existem no mundo sensível recebem seu ser ou são engendradas pelo seu grau imediatamente superior.

Assim, no sistema monista plotiniano, a matéria, que na sua união com a Alma universal dá origem aos seres corporais, é a última processão do Uno, e como tal, é eterna e necessária ${ }^{8}$. Esta, apesar do extremo distanciamento do Bem, não forma um princípio ontológico independente (como no maniqueísmo). Pois, apesar de ser, juntamente com a Alma universal, um dos princípios originantes da multiplicidade dos seres corpóreos, isso não significa que a matéria se constitua em um princípio ontológico originante de si mesma, pois, em nenhum momento das Enéadas Plotino fala de um segundo princípio ontológico originante. A matéria, assim como a Alma universal, faz parte, em última das instâncias, do $U n o^{9}$, ela é, assim, o extremo limite do Uno (para além dos limites da matéria não há mais processão algu-

8 FRAILE, 1956, p. 719: “A matéria é necessária porque o Universo consta de contrários, e não poderia haver contrários se não existisse a matéria”. E é claro que, sendo a matéria algo necessário, também o é o mal. Igualmente diz Edrisi Fernandes, seguindo as pegadas de Pietro Prini: “Em Plotino, portanto, o 'Mal em si' (observadas as aspas) tem certo estatuto fundacional em relação à existência; a tese de que 'o mal é um Princípio necessário, perenemente operante no "mundo cá de baixo", constitui sem dúvida alguma a originalidade da Enéade I.8. (2013, p. 134). 
ma, ou não existe mais nada), lugar da obscuridade, da multiplicidade e, portanto, fonte ou possibilidade do mal. Por isso, Plotino fala da matéria, quando de seu estado de natureza pura, ou seja, sem que esteja ainda unida à Alma do mundo, para com ela formar o ser, como privação ou defecção falta de forma, indeterminação, distanciamento do Bem - o não-Ser, a que Plotino dá o nome de "nada"

Aqui estamos diante de um importante elemento da ontologia plotiniano, que influenciaria profundamente na formação intelectual de Santo Agostinho; a noção de "nada", como equivalente ao conceito de "não-Ser", o qual teria grandes reflexos no seu pensamento futuro, especialmente no que concerne à solução do problema do mal.

Entretanto, apesar de Plotino ter definido o não-ser (ou o nada) como o "ilimitado", o "informe", o "indeterminado", isso, para Agostinho, ainda não resolvia plenamente o problema do mal, por tratar-se ainda de uma explicação natural, quando o coloca na matéria. Não que esta seja o mal em si, como pensavam os maniqueus, mas o lugar onde o mal acontece, já que ela é a possibilidade do mal, ou seja, a matéria é o mal enquanto potência e não enquanto ato.

De qualquer maneira, se a ontologia plotiniana ainda não resolvia plenamente o problema do mal, pelo menos Plotino serviu-lhe de ponto de partida, ou estimulador, para uma solução definitiva ${ }^{11}$. Pois, ao ler as Enéadas, Agostinho despertou para possibilidade de haver um contrário à substância, seja ela material, ou espiritual, ou seja, a não-substância - o não-ser ou o "nada". A partir daí, Agostinho daria um importante passo na busca de

9 Cf. BUSSOLA (1990, p. 41): “As emanações diminuem e se degradam à medida que se afastam do Uno; logo, num momento pode não haver mais luz, somente escuridão [...] mas, cuidado! pois essa escuridão está ainda no Uno. O último lampejo antes da escuridão é apenas a última forma de emanação do Uno, dentro do Uno".

${ }^{10}$ Vale salientar aqui, que o termo "nada" utilizado por Plotino significa tão-somente o estado mutável em que se encontra a matéria no seu eterno e contínuo movimento que dá origem aos seres múltiplos. Entretanto, apesar de ser mutável, fluida, informe, indeterminada, a matéria é algo real. Não é o nada absoluto do cristianismo, onde se diz que Deus criou o mundo do nada, ou melhor, se precisar de nenhuma matéria preexistente.

${ }^{11}$ A esse respeito, diz BETTETINI (1994, p. 76): "Para Agostinho a noção de nada dará a chave para o problema do mal, que ele buscava resolver apoderando-se da concepção maniqueia de um mal substancial [...]. Em termos ontológicos, o mal se revela agora como privação do ser e portanto de beleza e de bondade, tendência ao nada, enquanto, em termos éticos, o mal se configura como a livre escolha da vontade que prefere ir contra a ordem das coisas e tender para o corpóreo muito mais que para o divino". 
uma solução para o problema do mal, que começou a parecer como que "um tirar fora", uma privação, ou seja, o mal não é uma substância, não forma um ser, mas, pelo contrário, é ausência, defecção, do Bem - o não-ser:

Vi claramente que todas as coisas que se corrompem são boas: não se poderiam corromper, se fossem sumamente boas, nem se poderiam corromper, se não fossem boas. Com efeito, se fossem absolutamente boas, seriam incorruptíveis, e se não tivessem nenhum bem, nada haveria nelas que se corrompesse. De fato, a corrupção é nociva, e se não diminuísse o bem, não seria nociva. Portanto, ou a corrupção nada prejudica - o que não seria aceitável - ou todas as coisas que se corrompem são privadas de algum bem. Isso não admite dúvida. Se, porém, fossem privadas de todo o bem, deixariam inteiramente de existir. Logo, enquanto existem, são boas [...]. Portanto, todas as coisas que existem são boas, e aquele mal que eu procurava não é uma substância, pois, se o fosse, seria um bem (Conf., VII, 12, 18).

Portanto, se o neoplatonismo de Plotino fornecia os elementos conceituais necessários, para que Agostinho viesse a superar, mais tarde, o materialismo maniqueu, contudo, naquele momento, ainda não resolvia plenamente o problema do mal, posto que, ao identificar o "não-ser" ou o "nada" com a matéria informe e indeterminada, substrato do qual, em conjunto com a Alma do mundo, surgem os seres corporais, Plotino acaba por dar uma origem natural ao mal, que aparece como algo necessário na sua ontologia/cosmológico. Ou, em Plotino, ainda não se encontrava a noção de culpa ou responsabilidade frente ao mal. Daí dizer Regis Jolivet:

Plotino teve a imensa vantagem de colocá-lo no caminho das soluções que ele buscava obscuramente e, antes de tudo, de arrancá-lo de seu materialismo. Este foi o grande benefício que tirou da leitura das obras platônicas e isto basta para justificar toda a importância que Agostinho sempre reconheceu destas obras, para seu progresso à fé, já que o materialismo era a raiz de todos os seus erros. Entretanto, Agostinho serviu-se da doutrina plotiniana como de uma espécie de trampolim para saltar mais longe e mais alto [...]. Plotino representava a seus olhos só um meio, de nenhum modo um fim (1932, p. $99-100)$.

\section{A superação do neoplatonismo no cristianismo}

Os sermões de Ambrósio e as leituras neoplatônicas haviam dissipado certos danos intelectuais causados pelo maniqueísmo. Entretanto, seu coração ainda não estava purificado ou apto a encontrar a Verdade. Precisava 
vencer os dois últimos obstáculos que ofuscavam sua mente, a saber: os desejos carnais e o orgulho intelectual.

Quanto ao primeiro diz, nas Confissões:

Admirava-me de já Vos ter amor e de não amar um fantasma em vez de Vós. Entretanto, não permanecia estável no gozo de meu Deus. Era arrebatado para Vós pela Vossa Beleza, e logo arrancado de Vós, pelo meu peso, para me despencar, gemendo, sobre as ínfimas criaturas. Este peso eram os hábitos da luxúria (Conf., VII, 17, 23).

Quanto ao segundo, apesar disso, e ainda que carecesse das asas da humildade e da pureza de coração, tão necessárias para alcançar a Verdade, Agostinho encontra forças para elevar-se e vai ao encontro do monge Simpliciano $^{12}$, e fala-lhe acerca das importantes descobertas que fizera ao ler os escritos neoplatônicos. Este reforçou os méritos dos neoplatônicos, mas chamou-lhe a atenção para um grave erro: o orgulho (soberba) ou presunção do saber por parte destes. E apontou o orgulho intelectual como um dos males que sufocava e ofuscava o coração de Agostinho naquele momento, impedindo-o de ver a Verdade. E, como solução para tal problema, Simpliciano exalta a necessidade da humildade cristã e da graça redentora de Cristo; de reconhecer Cristo como único salvador, para se chegar à Verdade. Este aspecto faltava nos neoplatônicos e em Agostinho, pois, naquele momento, ele não conseguia entender o "Mediador de Deus e dos homens, Jesus Cristo homem, Deus soberano". Ou ele não entende como Jesus Cristo pôde humilhar-se ao ponto de encarnar-se, habitar entre os homens e morrer sobre a cruz, como ele mesmo diz: "Eu não era humilde, e eu não tinha a humildade de Jesus por meu Deus, nem sabia de que coisa poderia ser mestra a sua fraqueza" (Conf., VII, 18, 24). Simpliciano o faz ver que

os filósofos podem, a rigor, com as forças de seu pensamento - que a Verdade, por outra parte, dirige sempre secretamente - descobrir e mostrar aonde ir, mas não por onde ir; são capazes de elevar-se à contemplação da pátria feliz, mas não de habitá-la; vêem o fim, mas desconhecem os meios. É que se trata de algo muito distinto do especular: trata-se de vencer as paixões, de reformar o coração, de fortalecer a vontade, e isso não é possível senão pela graça de Cristo (JOLIVET, 1932, p. 103).

\footnotetext{
${ }^{12}$ Simpliciano, confessor espiritual de Ambrósio, fazia parte do círculo dos neoplatônicos cristãos de Milão.
} 
Por isso, escreve Agostinho, nas Confissões:

Uma coisa é ver de um píncaro arborizado a pátria da paz e não encontrar o caminho para ela, gastando esforços vãos por vias inacessíveis [...]; e outra coisa é alcançar o caminho que para lá conduz, defendido pelos cuidados do general celeste [...] (Conf. VII, 21, 27).

No final da conversa, Simpliciano, percebendo ser necessário que Agostinho se munisse daquela caridade em que se baseia o fundamento da humildade, quer dizer, de Jesus Cristo, para se chegar à Verdade, recomenda-lhe ler as Sagradas Escrituras, especialmente São Paulo, onde poderá encontrar o caminho que lhe faltava.

E foi o que fez Agostinho, conforme relata:

Por conseguinte, lancei-me avidamente sobre o venerável estilo (da Sagrada Escritura) ditada pelo vosso Espírito, preferindo, entre outros autores, o apóstolo São Paulo [...]. Compreendi e notei que tudo o que de verdadeiro tinha lido ali (nos livros platônicos) se dizia aqui realçado com a tua graça [...] (Conf. VII, 21, 27).

Com uma grande diferença: os livros platônicos, ao identificarem o Verbo de Deus - o Lógos de São João - com o Noûs - a razão, esqueciam de dizer que o Verbo se fez homem e habitou entre nós" (Jo 1,13). Por isso, diz:

Li nesse lugar (nos livros platônicos) - não certamente com estas palavras, mas sim substancialmente o mesmo, apoiado em muitas e diversas razões - que "no princípio era o Verbo, e o Verbo estava em Deus [...]. Também li ali que o Verbo, Deus, não nasceu da carne, nem do sangue, nem da vontade da carne, mas de Deus. Porém, que 'o Verbo se fez homem e habitou entre nós'(Jo 1,13), isso não li eu ali (Conf., VII, 9, 14).

E continua:

Igualmente li naqueles livros (dos platônicos), dito de diversas e múltiplas maneiras, que o Filho tem a mesma condição do Pai e que não foi injúria julgar-se igual ao Pai, por ter a mesma natureza que ele'. Mas que 'se anulou a si mesmo, tomando a forma de servo, feito semelhante aos homens e reconhecido como tal por seu modo de ser; e que se humilhou, fazendo-se obediente até à morte, e morte de cruz' [...], não o dizem aqueles livros (Conf., VII, 9, 14).

Por isso, depois de muitas outras comparações, mostrando o valor da humildade cristã como único caminho, para se alcançar a Verdade, o Cristo como mediador e redentor, conclui Agostinho: "Todas essas coisas penetra- 
ram-me até às entranhas, por modos admiráveis, ao ler (São Paulo) 'o mínimo de teus Apóstolos, e considerava suas obras, e me sentia espantado, fora de mim"” (Conf., VII, 21, 27).

A leitura de São Paulo, orientada pelos comentários de Simpliciano, fizera Agostinho perceber que, apesar de serem os que mais se aproximam das verdades da fé fé $^{13}$, que chegaram aos últimos limites do que a razão humana pode dizer de Deus, nos platônicos faltava um último degrau para se alcançar a verdade; que os neoplatônicos, ao identificarem o Verbo de Deus com o Nô̂s - ou razão natural, esquecerem que o Verbo não é somente Deus, mas Deus encarnado; que o "Verbo se fez carne e habitou entre nós".

Entendemos que, mais tarde, depois de convertido, Agostinho diria que os "platônicos" chegaram até às portas do céu, mas não entraram, atolando-se no seu próprio orgulho racional, ao pensarem que o mais alto grau da felicidade, a eudaimonia, se encerrava no pleno desenvolvimento da razão natural que eles imaginavam ter alcançado, ou como diz Dominique Courcelles:

Os platônicos acreditavam na autonomia espiritual dos homens. Pois, segundo seu discípulo Porfírio, estas teriam sido as últimas palavras de Plotino: 'Esforço-me por fazer remontar o que há de divino em nós ao que há de divino no universo'. Deste modo, o eu de origem divina não esperava uma libertação, só devia tomar consciência de sua origem divina (1998, p. 111).

Por isso, Agostinho, denunciando o seu próprio orgulho racional, durante o tempo que antecedeu sua conversão, e, ao mesmo tempo, o dos neoplatônicos ${ }^{14}$, diz:

\footnotetext{
${ }^{13}$ No tratado Sobre a Cidade de Deus (VIII, 5), diz: "Se Platão disse ser sábio quem imita, conhece e ama a Deus, de cuja participação depende ser feliz, que necessidade há de discutir as outras Doutrinas? Nenhuma se aproxima da nossa mais do que a deste".

${ }^{14}$ É por isso que, apesar de reconhecer a grande contribuição dos neoplatônicos, especialmente Plotino, cuja doutrina do Noûs é análoga ao Verbo de São João (cf. Conf., VII, 9,13 e De civ. Dei X, 29, 2), e Porfírio, no qual encontra-se uma teoria da Trindade, compreendendo o Pai, o Filho (chamado intelecto), e ainda uma terceira hipóstase, como termo intermediário (cf. De civ. Dei, X, 23), Agostinho lamenta que tais filósofos caíram em um lamentável fracasso, porque sua soberba envergonhava-os de confessar a encarnação do Verbo. Agostinho dedicaria três livros inteiros do tratado Sobre a Cidade de Deus (Livro VIII a $\mathrm{X}$ - intitulados, respectivamente, "Teologia Natural e Filosófica", "Cristo Mediador" e "O Culto ao Verdadeiro Deus", para elogiar a filosofia platônica, mas, também, para mostrar os seus limites, ou seja, que pela razão filosófica não se chega à verdade, mas, tão-somente, a uma falsa verdade, ou soberba.
} 
Tagarelava a boca cheia como um sabichão, mas, se não buscasse em Cristo Nosso Salvador o caminho para Vós, não seria perito, mas perituro $^{15}$. Já então, cheio do meu castigo, começava a querer parecer um sábio; não chorava e, por acréscimo, inchava-me com a ciência (Conf., VII, 20, 26).

As palavras de São Paulo mostraram-lhe que a "verdadeira sabedoria", sinônimo de "verdadeira felicidade", não se encontra neste mundo, mas tão-somente em Deus, e que Este não se atinge pela razão, mas, para alcançá-Lo, é preciso transcender a razão; que só mediante a humildade cristã $^{16}$, pela gratuidade de pensamento, por contemplação, o homem pode alcançá-Lo. Era a luz que faltava para clarear o espírito e esquentar o coração de Agostinho.

\section{A genuína solução agostiniana do mal, no cristianismo}

Munido dos dados da fé e dos instrumentos conceituais do neoplatonismo, os quais irá converter em conceitos cristãos Agostinho continuará sua busca por uma solução para a questão do mal.

Logo após a conversão, por um período de cerca de dez anos (386 à 405), concentrará todas as suas forças no combate à doutrina maniquéia. Era preciso combater a ideia maniqueia de que a origem do mal se encontra no universo físico, mais especificamente na matéria. Essa tese entrava em confronto com a ideia judaico-cristã do Deus-Uno-Criador, que fez todas as coisas naturalmente boas, inclusive a matéria. Por isso, Agostinho iria iniciar suas teses refutatórias, a começar pela obra De Ordine, escrita no "retiro de Cassicíaco", pela construção de uma nova ontologia/cosmologia-fílosófico/ religiosa que salvaguardasse esses princípios judaico-cristãos.

\footnotetext{
15 "Perito" - Verdadeiro saber que leva à salvação. "Perituro"- Falso saber que leva à morte, ou à condenação. Igualmente, no tratado $A$ Cidade de Deus (IX, 20), inspirado nas palavras do Apóstolo: "A ciência infla e a caridade edifica", Agostinho denuncia: "A ciência não é útil senão quando acompanhada pela caridade e, sem a caridade, a ciência infla o co ração e o enche do vento da vanglória. Assim, os demônios têm a ciência sem a caridade". ${ }^{16}$ Mais tarde, em Sobre a Trindade (XIII, 17, 22), Agostinho voltaria a apresentar a Cristo, ou o Verbo encarnado, como remédio para curar o orgulho no homem: "A soberba humana, principal obstáculo para a união com Deus, foi corrigida e medicada pela humildade profunda de Deus". Também no tratado Sobre a Cidade de Deus, Livro IX, capítulo 15, intitulado "Jesus Cristo, homem, mediador entre Deus e os homens", Agostinho mostra que só pela humildade cristã, com a aceitação do Cristo redentor, o Verbo encarnado, podemos alcançar a verdade.
} 
Assim, primeiramente, partindo do princípio bíblico da criação ex nihilo, e da noção plotiniana de participação, Agostinho demonstrará, contra o dualismo maniqueu, que todos os seres do universo, inclusive a matéria, vieram de um único princípio - Deus -, não por emanação, mas por criação, não por necessidade, mas por um ato livre de amor, a partir do nada. Com isso, refutou todas as objeções que os maniqueus faziam ao tema, e que tinha sido uma das pedras de tropeço na compreensão da Bíblia, quando a leu pela primeira vez, logo após a leitura do Hortensius, na juventude. Ao mesmo tempo mostrou que, no universo criado por Deus, não há espaço para desordem natural, nem para o acaso, mas que tudo obedece à ordem estabelecida por quem tudo criou e tudo mantém sob seu governo. Até mesmo os casos particulares ou isolados, julgados pelos homens como disformes ou males, Agostinho, partindo dos conceitos de totalidade, unidade e harmonia, diz que parecem como tais devido à visão deturpada do homem. Este, em virtude da ofuscação de sua mente provocada pelo pecado, não consegue ver o todo e, julgando a parte pelo todo, concebe-a como má; mas, na totalidade, o universo é perfeitamente harmonioso, nas partes e no todo. Como ele observa, tais males, ou melhor, aquilo que os homens chamam de males, não só não são propriamente males, mas se enquadram perfeitamente ou até contribuem para a harmonia do universo. E Deus, de sua parte, não só os permite, mas até tira bons proveitos deles para o governo do mundo.

Portanto, para Agostinho, no universo criado e governado por Deus não há espaço para o mal físico, e o mal não pode ser definido como uma substância, visto ser toda a natureza um bem. E, radicalizando o conceito neoplatônico de "não-ser", conclui que, apesar de ser justamente nos seres criados que o mal acontece, visto serem apenas participação da suma bondade de Deus e, por isso, estarem sujeitos à mutação, contudo, o mal não se define como uma característica intrínseca do ser, não faz parte da essência do ser, que em si é sempre um bem. O mal, como o contrário da natureza, caracteriza-se por uma ausência do que deveria ser, ou pelo que ele não é; é uma corrupção que arrasta ou leva tudo em direção ao não-ser. Portanto, o 
mal é a corrupção, e como tal não tem consistência ontológica, é simplesmente "não-ser" ou "nada" 17 .

Entretanto, apesar de ter defendido, contra os maniqueus, que no universo criado e governado por Deus não há espaço para o mal físico, nesse momento, a investigação agostiniana ainda se situava no nível da explicação ontológico-estética dada pelos neoplatônicos, muito embora tenha adquirido uma roupagem religiosa, ao adotar como ponto de partida de sua nova cosmologia o princípio ontológico-teológico da criação ex nihilo. Mas tal posição ainda não resolvia plenamente o problema do mal, mas só parcialmente, quando, por ela, se chegava apenas a uma definição do que seja o mal, respondendo à pergunta: que é o mal? Melhor dito, chegava à conclusão do que ele não é (de que ele não forma uma substância ou natureza em si), visto que em si ele não é senão o "não-ser" ou o "nada". Entretanto, restava saber: afinal, qual a causa dessa força misteriosa, que em si não é nada, mas que leva os seres ao não-ser?

O último nível da resposta agostiniana a esta questão encontra-se já na obra De Libero Arbitrio, iniciada logo após o "retiro de Cassicíaco" e terminada mais tarde na África, e que seria seguida em seu conteúdo por algumas outras. Já no final do Livro I, Agostinho anteciparia aquela que seria a conclusão geral da obra (e por que não dizer a resposta definitiva ${ }^{18} \mathrm{em}$ toda sua doutrina) acerca do problema do mal, quando defende que a causa ou origem do mal está no livre arbítrio da vontade humana. O conceito-chave para entender esse momento está na palavra "pecado", que traz em si uma conotação moral, ou a ideia de culpa (malum culpae) ou responsabilidade, por apresentar o pecado (o mal) como fruto do abuso da livre vontade, ou do mau uso da vontade livre por parte do homem.

\footnotetext{
${ }^{17}$ A esse respeito diz RICOEUR (1988. p. 32): "Dos filósofos (platônicos), Agostinho sustenta que o mal não pode ser entendido como substância, pois pensar o 'ser' é pensar 'inteligivelmente', pensar o 'uno', é pensar o 'bem'. Então, o pensar filosófico exclui todo o fantasma do mal substancial. Por outro lado, nasce uma ideia de nada, e do ex nihilo, contida na ideia de uma criação total sem excesso".

${ }^{18}$ Chamamos a atenção de que a palavra "definitiva" aqui usada, não significa que Agostinho tenha resolvido definitivamente o problema, ou que não tenha escrito mais nada acerca do problema até o final de sua vida, mas no sentido de que, ontologicamente, este é o último estágio de sua explicação. Ou seja, não há um segundo lugar ou princípio ontológico no qual Agostinho coloque a causa ou origem do mal, o livre-arbítrio da vontade humana será para ele, até o final de sua vida, a causa ou origem do mal.
} 
Assim, o único mal que podemos chamar propriamente de mal é o mal ético-moral, pois o mal metafísico não existe, é antes não-ser; e o mal físico não passa de um erro de perspectiva estética, por parte do homem, e é perfeitamente abarcado na totalidade do universo. Nesse momento, Agostinho alcançaria o último estágio de seu pensamento acerca do problema do mal, passando de uma explicação ontológico-estético-filosófico-religiosa a uma explicação ontológico-ético-moral-filosófico-religiosa do problema. E é aqui, defendemos, que reside toda a originalidade do pensamento de Agostinho em relação aos filósofos que o antecederam, dentre eles os neoplatônicos, conforme acentuam diversos comentadores ${ }^{19}$.

E, para mostrar como o mal acontece nos seres criados, mais especificamente no livre arbítrio do homem, começa por demonstrar as seguintes premissas: a) o homem é o único animal que possui alma dotada da faculdade da razão; b) isso o torna superior aos demais animais; c) e, portanto, tem a capacidade de conhecer; d) pela iluminação divina percebe a justa ordem estabelecida por Deus, segundo a qual não devemos antepor as coisas inferiores às superiores; e) e conhecendo-a, pode escolher entre seguir a ordem, aproximando-se assim do Criador, o único que pode fazê-lo feliz, ou afastarse da ordem, criando a desordem, que é o mal, caminho da infelicidade. Após, servindo-se do conceito neoplatônico de mal, como privação, defecção, ausência ou distanciamento do bem - não-ser -, define o mal justamente como o distanciamento ou afastamento de Deus, por parte do homem, que, por livre vontade, escolhe direcionar todo seu amor às coisas inferiores, dentre elas a si mesmo, gerando a soberba, em detrimento do amor devido a Deus.

\footnotetext{
${ }^{19}$ Dentre os comentadores destacamos ALVAREZ-TURIENZO (1954. p. 92) que diz: "Nunca o saber encontrou o caminho para o adequado tratamento do negativo no Ser; em todo caso, o antigo não aceita em conceber esse lado negativo como mal, e muito menos como pecado, como especificamente ético. Concebeu-o melhor como um princípio autônomo, um sucesso fatal; e, quando se surpreendia na conduta, pensava-se ao modo de uma contaminação física [...]. O mal era algo exterior, necessário, irredutível e físico".
} 


\section{Referências}

AGOSTINHO, Santo. A Trindade. Tradução e notas: Augustino Belmonte. São Paulo: Paulus, 1994. 726 p. (Coleção Patrística, n. 7).

AGOSTINHO, Santo. Confissões. Tradução: Maria Luiza Jardim Amarante. São Paulo: Paulus, 1998. 221 p. (Coleção Patrística, n. 10)

AGOSTINHO, Santo. A cidade de Deus: contra os pagãos. Tradução: Oscar Paes Leme. 3. Ed. Petrópolis: Vozes; São Paulo: Federação Agostiniana Brasileira, 1991. v. I, 414; v. II, p.589.

ALVAREZ-TURIENZO, Saturnino. "Entre los maniqueus y los pelagianos: iniciación al problema del mal en San Agustín". Revista La Ciudad de Dios. Madrid, v. 166, 1954. p. 87-125.

BARDY, Gustave. Saint Augustin: l'homme et l'oeuvre. 4 ed. Paris: Desclée de Brouwer, 1940. 528 p.

BETTETINI, Maria. La misura delle cose: estruttura e modelli dell'universo secondo Agostino d'Ippona. Milano: Rusconi, 1994. 268 p.

BRACHTENDORF, Johannes. The structure of the human mind according to Augustine: self-reflection and knowledge of God in De Trinitate. Translation: Aaron Looney. Hamburg: 2000. 339 p.

BUSSOLA, Carlo. Plotino: a alma no tempo. Vitória: FCAA/UFES, 1990. $61 \mathrm{p}$.

COURCELLES, Dominique de. Agustín o el genio de Europa. Tradución: Francisca Santa Cruz L. Caracas: Dolmen Ediciones, 1998. 318 p.

FERNANDES, Edrisi. “ A "superação" schellinguiana do entendimento plotiniano da transição do bem para a matéria e o mal”. Archai, n. 10, jan-jul, 2013, p. 127-140.

FRAILE, Guillermo. "Plotino". In: FRAILE, Guillermo. Historia de la filosofia: Grecia y Roma. Madrid: La Editorial Catolica, 1956. vol I, p. 703 735.

JOLIVET, Regis. San Agustín y el neoplationismo cristiano. Tradución: G. Blanco ; 0. Iozzia ; M. Guirao ; J. Otero ; E. Pironio y J. Ogar. Buenos Aires: Ediciones C.E.P.A, 1932. 219 p.

O'MEARA, John J. La jeunesse de saint Augustin: son évolution intérieure jusqu' à l'époque de la conversion. Traducion: Jeanne Henri Marrou. Paris: Librairie Plon, 1954. 277 p.

PLOTINO. Enneadi. Traduzzione: noti di Giuseppe Faggin. 4 ed. Milano: Rusconi, 1996. 1602 p. 
RICOEUR, Paul. O mal: um desafio à filosofia e à teologia. Tradução: Maria da Piedade Eça de Almeida. Campinas: Papirus, 1988. 53 p.

SCIACCA, Michele Federico. San Agustín. Tradución: Ulpiano Álvarez Díez. Barcelona: Luis Miracle, Editor, 1955. Tomo 1, 495 p.

TURRADO, Argimiro. "El problema del mal y la responsabilidad moral de las personas especialmente en la "Ciudad de Dios" de s. Agustín". Revista Agustiniana, 1995. p. 733-789 